\section{JCEFTS 1,2}

\section{8}

\title{
Interdependence of income between China and ASEAN-5 countries
}

\author{
Evan Lau \\ Department of Economics, Faculty of Economics and Business, \\ Universiti Malaysia Sarawak (UNIMAS), Sarawak, Malaysia, and \\ Koon Po Lee \\ UMW Corporation Sdn Bhd (Oil and Gas), Kuala Lumpur, Malaysia
}

\begin{abstract}
Purpose - The purpose of the paper is to empirically examine the interdependence of income
between China and ASEAN-5 countries by using the real gross domestic product (GDP). Besides
answering this important policy question, the paper is also concerned with ascertaining the causal
direction between China and the ASEAN-5 income.
Abstract
Purpose - The purpose of the paper is to empirically examine the interdependence of income
between China and ASEAN-5 countries by using the real gross domestic product (GDP). Besides
answering this important policy question, the paper is also concerned with ascertaining the causal
direction between China and the ASEAN-5 income.

Abstract
Purpose - The purpose of the paper is to empirically examine the interdependence of income
between China and ASEAN-5 countries by using the real gross domestic product (GDP). Besides
answering this important policy question, the paper is also concerned with ascertaining the causal
direction between China and the ASEAN-5 income.

Abstract
Purpose - The purpose of the paper is to empirically examine the interdependence of income
between China and ASEAN-5 countries by using the real gross domestic product (GDP). Besides
answering this important policy question, the paper is also concerned with ascertaining the causal
direction between China and the ASEAN-5 income.

Abstract
Purpose - The purpose of the paper is to empirically examine the interdependence of income
between China and ASEAN-5 countries by using the real gross domestic product (GDP). Besides
answering this important policy question, the paper is also concerned with ascertaining the causal
direction between China and the ASEAN-5 income.

Design/methodology/approach - The paper resorts to the standard time series econometrics analysis. These includes the unit root, cointegration and the Granger causality tests in order to test the causal interplay and interdependence of income between ASEAN-5 and China for the estimation period from 1960 to 2003 obtained from the Penn World Table (PWT) 6.2.

Findings - Empirical results are found to support the strong interdependence of income between China and ASEAN-5 countries. Further, the causality experiment suggests that China is the key factor in connecting (equilibrium point) the ASEAN-5 region, where China in one-way or another marks the resemblance of the income amongst these economies.

Originality/value - The paper is of value in that it highlights the issue of interdependence of income especially in developing countries. With the increasing interest of economic integration around the globe especially the China-ASEAN Free Trade Area (CAFTA), the interdependence and synchronization movements of income between member countries is an important characteristic for suitability towards the regional common currency goal.
\end{abstract}

Keywords China, South East Asia, Free trade, Income, International cooperation

Paper type Research paper

\section{Introduction}

The rapid development of the People's Republic of China has drawn much attention in recent years. Being prosperous and holding pride as the second largest world economy (after the USA) in recent years, its gross domestic product (GDP) stood at USD10.21 trillion in 2006[1]. There had been annual consistent high growth rate averaging above 10 percent in China for the past decade and this had significantly caused an outburst upon the world economies. This is particularly true especially among its neighboring regional economies of the ASEAN-5 (Indonesia, Malaysia, Philippines, Indonesia and

A shorter version of this paper was presented at the Regions on a Global Platform 9th PRSCO, Summer Institute, Kuala Lumpur, Malaysia in July 2006. Comments from the Conference participants provided insights that led to the improvement of the paper. The authors would like to thank Professor Junjie Hong (the Executive Editor of this journal) and the two anonymous referees for their helpful comments and suggestions on the earlier draft. As usual, the responsibility for errors and omissions rests with the authors.
Journal of Chinese Economic and Foreign Trade Studies

Vol. 1 No. 2, 2008

pp. 148-161

(C) Emerald Group Publishing Limited $1753-4408$

DOI $10.1108 / 17544400810884718$ 